\title{
Rare Metal Deposits of East Kazakhstan: Geologic Position and Prognostic Criteria
}

\author{
Boris Dyachkov $^{1,2}$, Natalya Zimanovskaya ${ }^{1}$, Indira Mataibayeva ${ }^{1}$ \\ ${ }^{1}$ D. Serikbayev East Kazakhstan State Technical University, Ust-Kamenogorsk City, Kazakhstan \\ ${ }^{2}$ Altai Geological and Ecological Institute, Ust-Kamenogorsk City, Kazakhstan \\ Email: bdyachkov@mail.ru,Nata_Zim@mail.ru, indi.mataybaeva@mail.ru
}

Received September 9, 2013; revised October 8, 2013; accepted October 16, 2013

Copyright (C) 2013 Boris Dyachkov et al. This is an open access article distributed under the Creative Commons Attribution License, which permits unrestricted use, distribution, and reproduction in any medium, provided the original work is properly cited.

\begin{abstract}
In the article the features of the formation and metallogeny of the geological structures of Great Altai (Rudny Altai, Kalba-Narym, Western Kalba and Jarma-Saur) which are included into the system of the Central Asian mobile belt are considered. The characteristic of the main types of rare metal minefields of the Kalba-Narymsky belt genetically connected with the Perm granitoid magmatism of the post-conflict orogenny stage of activization is given. The rhythmical and pulsation model of pegmatitovy ore formation in the conditions of the half-closed magmatic system, reflecting the phasic development of mineral complexes from graphic and oligoclase-microcline (barren) to microcline-albite and albite-spodumene ore ( $\mathrm{Ta}, \mathrm{Nb}, \mathrm{Be}, \mathrm{Li}, \mathrm{Sn}$, etc.) is developed. On the basis of the revealed criteria of ore formation recommendations about the direction of the further researches are made.
\end{abstract}

Keywords: Rare Metals; Pegmatite; Albitite-Greisen Metasomatits; Kalba-Narym Belt; East Kazakhstan

\section{Introduction}

The examined territory is a part of the Central-Asian mobile belt zone and unites geological structures of Great Altai including Rudny Altai, Kalba-Narym, Western Kalba both Jarma-Saur and abuted areas of Russia and China (Figure 1). Borders are the northwest deep breaks separating hercine structures of Great Altai from caledonide formations of Gorne Altai (in the northeast) and Chingiz-Tarbagatay (in the southwest). General extent of territory is more than $1000 \mathrm{~km}$ while $300-400 \mathrm{~km}$ at width.

The Kalba-Narym zone is composed of Upper Devonian and Carboniferous terrigenous rock that are intruded by the major Kalba-Narym granitic pluton. The main litologies are granodiorite, granite and leucogranite, aplitelike granite, aolite dikes, pegmatite and quartz veins. Early granitic rocks are assigned to the Kalba Complex $\left(\mathrm{P}_{1}\right)$, whereas the later leucogranite is referred to the Monastyrsky Complex $\left(\mathrm{P}_{2}\right)$.

Rare metal pegmatite deposits in the Central Kalba ore district (Yubileinoe, Belogorskoe, Verkhne-Baimurzinskoe, Ognevskoe, etc.) are of the most economic importance. Two deposits of the pegmatittype (Yubileinoe) and greisens-quartz vein type (Cherdoyak) are discussed in the text below.

Last years from new theoretical positions-the hy-

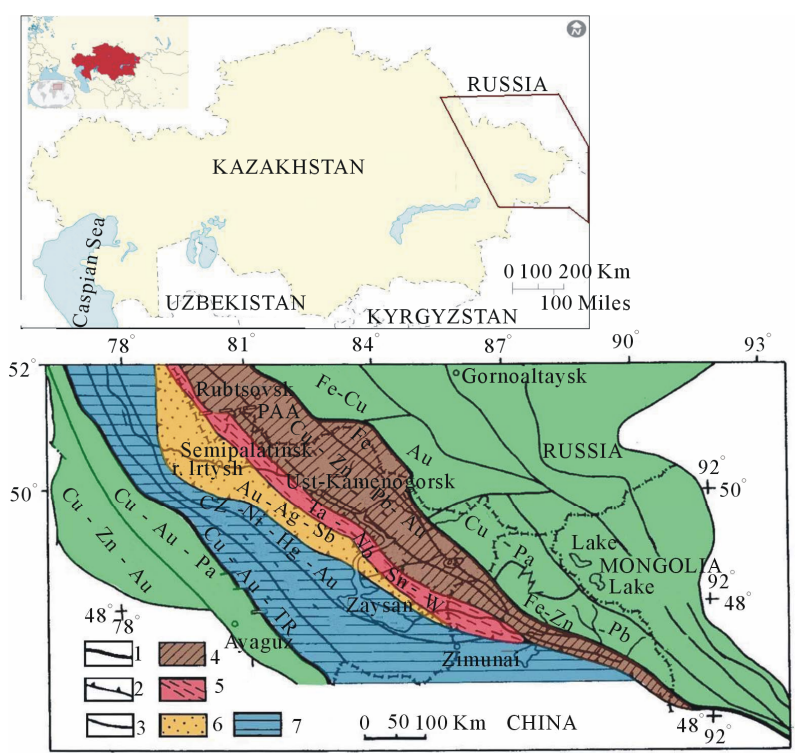

Figure 1. Dreat Altai metallogeny division into areas. 1border of Dreat Altai; 2-of ore belts and 3-of metallogenic zones; 4-Rudnoaltaisky, 5-Kalba-Narymsky, 6West-Kalbinsky and 7-Zharma-Saursky ore belts. 
potheses of global mobilization problematic questions of geodynamic development of Great Altai main ore-bearing structures were considered. The results of researches are published in the monography "Great Altai" [1,2].

\section{The Geological and Metallogenic Evolution}

The formation of geological structures contacts to general geodynamic model of Paleoasiatic ocean evolution and was defined by system of complex cooperating continental lages of the Siberian and Kazakhstani subcontinents. Modern geological structures of region are tectonic enclave of ancient paleocontinents and litospheric blocks (or collage terrains), which drifted in Paleasiatic ocean and have confronted in the process of hercinic collision $\left(\mathrm{C}_{1}-\mathrm{C}_{2-3}\right)$, having formed uniform structure of Great Altai [3-5].

According to the region's metallogeny we allocate here four ore belts of a belt zone: Rudnoaltai (copperpolimetallic), Kalba-Narym (rare metals), West-Kalba (gold ore) and Zharma-Saur (multimetal) [2,6]. The geological formation development and mineralization occured in a mode of oceanic riftogene $\left(\mathrm{PR}_{3}\right)$, then in early (riftogenic, islandarcic), average (collision) and late (postcollision) stages of coledanic and hercynic cycles, and was finished by continental riftogenes and neotectonic orogeny in mesozoic and cainozoic $[1,6]$. In Precambrian during the process of proterozoic base riftogenes in mantled breaks magmatics deposits of a $\mathrm{Cr}, \mathrm{Ni}$, $\mathrm{Co}(\mathrm{Pt}, \mathrm{Hg})$ were generated. In Rudny Altai in riftogenic stage $\left(D_{1-3}\right)$ were formed large pyritespolimetallic deposits of volconogenic genesis- $\mathrm{Cu}, \mathrm{Pb}, \mathrm{Zn}, \mathrm{Au}, \mathrm{Ag}$ etc. (Zyryanovsk, Maleevsky, Ridder-Sokolny, Artemevsky etc.) $[2,6-8]$. For an average conflict stage $\left(\mathrm{C}_{1-3}\right)$ sulphidic copper-nickel, copper-porphiry and gold ores deposits connected with magmatigm of gabbro-dioritgranodiorit-plagiogranit series are characteristic. The most significant deposits of gold (Bakyrchik, Suzdal etc.) were located in Zaisan suturn zone generated on continental edges interfase $[6,9,10]$. In a late stage $\left(\mathrm{P}_{1}-\mathrm{T}_{1}\right)$ under the conditions of innerslabs activation were generated granitoid belts (zone) with rare metals and rare earths ores, placed on lithospheric blocks borders. In cimmerian cycle in conditions of continental riftogenesis and subsequent stabilization the deposits of crustores (Ni-Co, $\mathrm{Zr}-\mathrm{Ti}-\mathrm{Au})$ were formed.

Thus, main rare metal-bearing structures of granitoid region belt have appeared during late hercynion activization differing on geotectonic position, the scale of development, internal structure, material structure and orebearing (Figure 2). Natural spatial time of rare metals belts to tectonic weakened zones in continental blocks terrestrial crust of raised sialic is established. There is marked northwest line and significant extent $(500-800 \mathrm{~km})$.

\section{Kalba-Narym Belt}

Kalba-Narym belt is the largest adjoining to Irtysh shear zone and extends in the northwest direction on $500 \mathrm{~km}$ and further proceeds in Russia and China. On the geology-geophysical data it is supposed, that this granitoid belt is placed in a head part of huge techtono-magmatic zone, steep fallic on the northeast under Rudny Altai [2]. The centers of magmaformation arose, by granite melts structure in metagranited layer or on its border with metadiorited layer. The transit ore-bearing solution have penetrated from the bottom parts of Earth crust and top mantle on system of deep breaks $[2,11]$.

The belt is combined with mainly normal granits and leucogranits of the Perm age, to which the deposits of rare metals are generically connected $(\mathrm{Ta}, \mathrm{Nb}, \mathrm{Be}, \mathrm{Li}, \mathrm{Cs}$, $\mathrm{Sn}, \mathrm{W})[12,13]$.

We allocate the following ore formations types of deposits:

1) pegmatitic rare metals $(\mathrm{Ta}, \mathrm{Nb}, \mathrm{Be}, \mathrm{Li}, \mathrm{Cs}, \mathrm{Sn})$, submitted by the main industrial deposits (Bakenny, Belaya Gora, Yubileiny etc.);

2) pegmatic beryl-microcline in which mineral deposits are blocked microcline and quartz, muscovite, beryl and columbite (deposits: Asubulak, Lobaksai, NijneLaibulak etc.);

3) albite-greisen tin-tantalitic (apogranitic) in the latent granite domes, potentially perspective on revealing $\mathrm{Ta}, \mathrm{Sn}, \mathrm{Be}, \mathrm{Li}$ (Karasu deposit);

4) greisen-guartz vein cassiterite wolframic submitted by ores of wolframite, scheelite and cassiterite (Cherdoyak, Palasy, Kaindy deposits, etc.);

5) clastogene tantal-cassiterite-wolframic, forming tantalite looses, cassiterite, wolframite, scheelite and monazite.

\subsection{The Model of Rare Metal Pegmatite Deposits}

The basic model of formation for main industrial rare metal - pegmatite of Kalba-Narym belt deposits is defined by their genetic connection with granite kalba of complex $\mathrm{P}_{1}$ and spatial accommodation of ores veins mainly in granite files and their exocontact (Figure 3). The processes of pegmatite formation probably occured in open or semi-closed magmatic system at rhythmicpulsating receipt of ore-bearing distillates $\left(\mathrm{H}_{2} \mathrm{O}, \mathrm{F}, \mathrm{B}, \mathrm{Cl}\right.$, $\mathrm{Ta}, \mathrm{Nb}, \mathrm{Be}$ etc.) from cameric center of granite files (under the conditions of the increased activity of ore-controlling breaks). Pulsating receipt of ore-bearing solutions has determined multirhythmical zones of ash value pegmatic veins, the colour quartz-lepidolite-cleavelandite and spodumene with rich complex ores $(\mathrm{Ta}, \mathrm{Nb}$, $\mathrm{Li}, \mathrm{Cs}, \mathrm{Be}, \mathrm{Sn}$ ) and increasing concentration of mineralization veins stagic development of mineral complexes from oligoclase-microcline up to albite. 


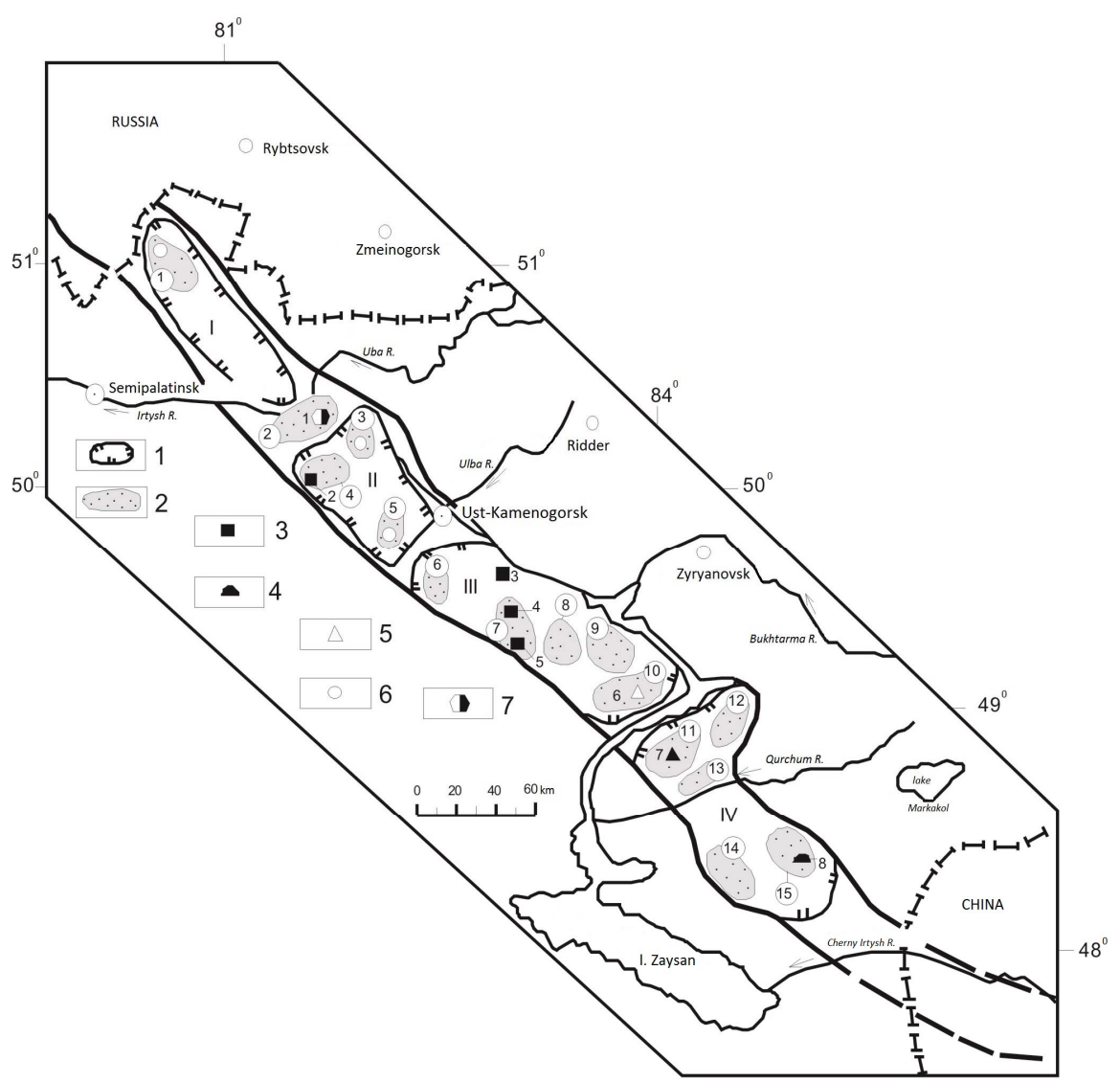

Figure 2. Kalba-Narym rare-metal belt [6]. Boundaries of (1) ore belts and (2) ore clusters; (3 - 7) types of deposits: (3) rare-metal pegmatites, (4) Sn- and Ta-bearing albitite and greisen, (5) greisens and quartz veins, (6) Sn-W quartz veins, (7) copper-pyrrhotite massive sulfide deposits. Ore districts (numerals in figure): I—Shulba; II-Northwest Kalba; III—Central Kalba; IV Narym. Ore clusters (numerals in circles): 1-Stepanovsky; 2-Vavilonsky (copper); 3-Mokhnatukhinsky; 4Ubinsky; 5-Yuzhnoproletarsky; 6-Saryozek; 7-Asubulak-Belogorsky; 8-Manat-Chernovinsky; 9-Voilochevsky-Kosheminsky; 10—Mirolyubovsky; 11—Leninsky-Cherdoyak; 12—Kasatkinsky-Bulandinsky; 13—Burabai; 14—Tortqalmak; 15-Karasu; deposits (numerals in figure): 1-Vavilon; 2-Kvartsevy; 3-Bakenny;4-Yubileiny; 5-Belaya Gora; 6Palatsy;7-Cherdoyak; 8-Karasu.

The carried out researches have shown, that ore-generating ability of granitoide, alongside with petrologic by the factors, in many respects depends on geodynamic conditions stand of files and scales degasazion ore-bearing solution melts $[2,6]$. From these positions certain oremagmatic systems differing on the scale miner were planned.

The above-intrusive system of active interaction granite intrusion with lateral breeds raised carbonaceous and calcindition in mobile tectonic conditions. Rare metal mineralization ( $\mathrm{Ta}, \mathrm{Nb}, \mathrm{Be}$ and others) concentrated in a frontal part of stratified intrusivic bodies, in their apofise and branches, and also in lateral breeds of eksocontakte. The main industrial type is Bakenny deposit (Figure 4).

The inside-intrusic system of cameric conter formation of ore pegmatite veins in granite files complicated by explosive tectonic. Ore-controlling was the regional breaks of sublatitudic stream line, opening residual cameric of ore-bearing melts, and ore-locading were zones raising cracks and zones of increased fissing and independent system of cracks in granite at oreformation rare metal pegmatites of albite subformation, uniting various mineral complexes (albite-microcline, albite, albite-spodumene etc) were generated. Ore bodies contain the unique minerals clevelandit, coloured and polychrome tourmalines, lepidolite, spodumene, petalite, pollucite and othres. The deposits have industrial values (Yubileiny, Belaya Gora, Upper Baymurza etc.) [2,6,7, 14]. These objects are compared with the large pegmatite deposits in other regions-Bernic Lake (Canada), Koktokay (China) and other [15-17].

\subsection{Types of Deposits}

System of ore-bearing granite domes. It is characterized by concentration of Sn-Ta mineralization in albitic and greisenic granite intrusive-above-intrusive zone of a blind dome (type Karasu) (Figure 5). Rare metal mineralization is generically connected with medium musco- 


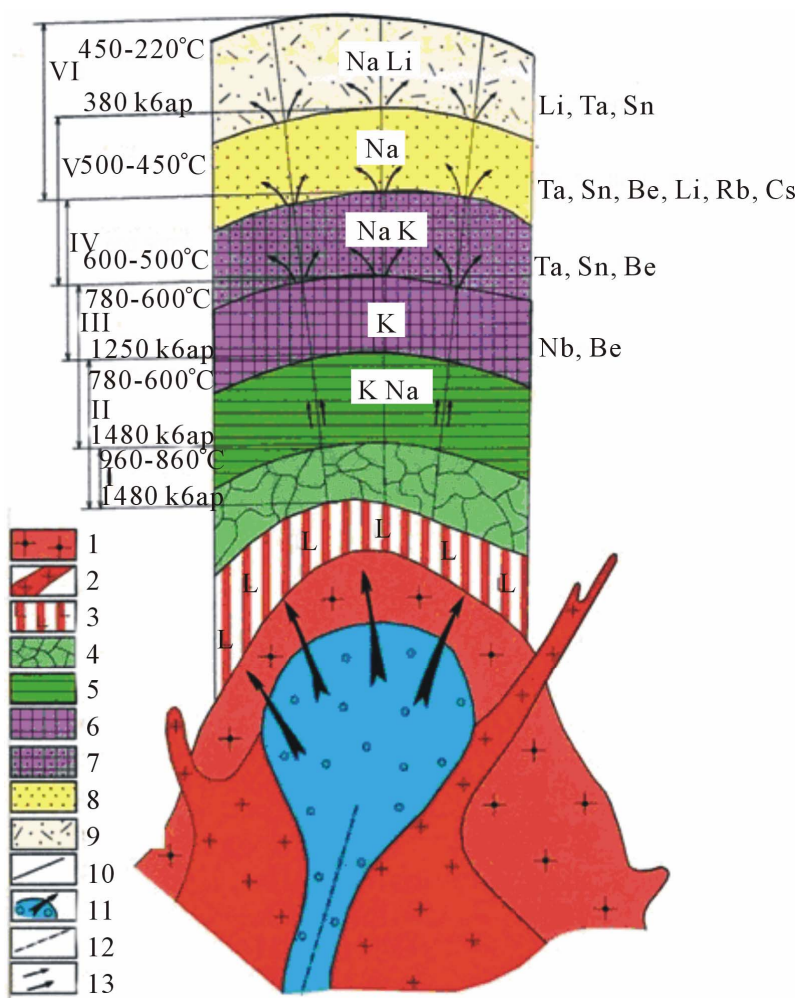

Figure 3. A model formation pegmatite rare deposits. 1coarse-and medium-biotite granite; I phase and 2-fine-and medium-grained muscovitized granite, II phase kalba complex $\left(P_{1}\right) ; 3$-aplite-like, aplite; 4 - 10-pegmatites (4oligoclase-microcline barren, 5-grafic, 6-microcline in blocks with beryl and columbite 7-microcline-albite with tantalite, cassiterite, beryl (rarely spodumene), 8-albitic (productive) with tantalite, cassiterite, beryl, pollucite, spodumene, lepidolite; 9-albite (cleavelandite)-spodumene, with tantalite, amblygonite, petalite, polychromatic tourmaline; 10 -faults; 11, 13 - direction of the fluid movement; 12 -ore-controling deep fault.

vite phase of granites the II phase of Kalba complex. The latter on geochemical features are referred to Sn-W-Ta type of ore-bearing granite close to liti-ftoric granite according to W. I. Kovalenko (1977).

The prognosic resources of tantalite and tin are significant.

System of imposed rare metal mineralization. It is characterized by migration of ore-bearing fluidizations from crystallizing granite melts in the tectonic weakened zones in containing breeds and imposing here mineralization on earlier hypabyssal small intrusions and dykes of Cunush complex $\mathrm{C}_{3}$. The latter became favorable physics-chemical environment for adjournment and concentration of mineralization, acting in a role of structural - litologic and geochemical traps (deposits Medvedka, Tochka etc.).

The system field of dispersion $R E$ is typical for large files of leucogranite Monastyr complex $\left(\mathrm{P}_{2}\right)$, which differ by flying and mineralizer riches $\left(\mathrm{H}_{2} \mathrm{O}, \mathrm{F}, \mathrm{B}\right.$ etc.) and

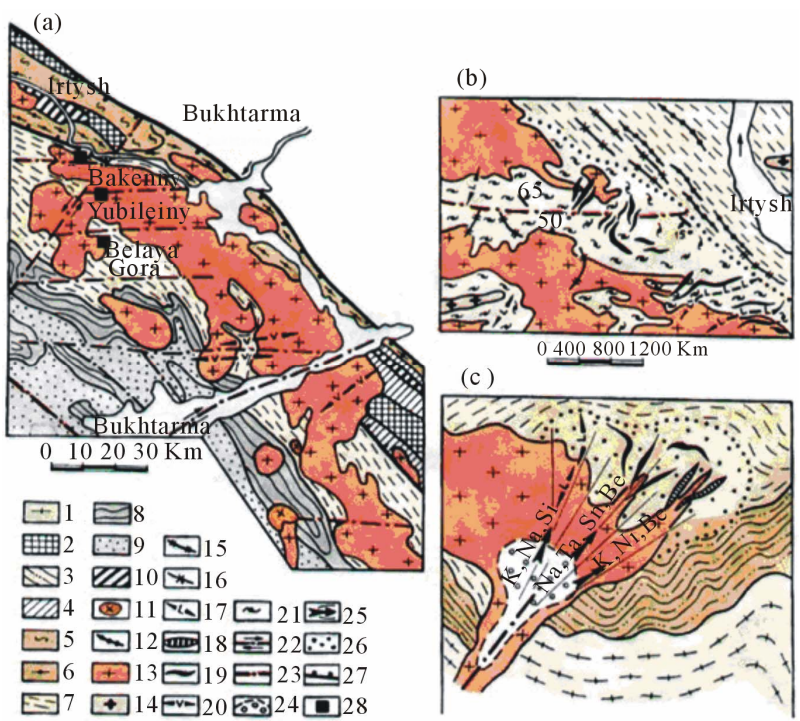

Figure 4. Bakennoe pegmatite deposit. (a)_arrangement plan of the pegmatite deposites; (b) - deological composion and (c)-geology-genetic model of the Bakennoe deposit. 1-granitic-metamorphic layer; 2-blocks of pregercynic basement; 3-calcic-terrigenous sediments of kystav-kurchumskoy series $\left(\mathrm{D}_{2} \mathrm{gv}\right) ; 4$ - 6-metamorfoseds sediments $\left(D_{1-2}\right)$; 7 - carbonaceous-sandstone-aleurolite sediments $\left(D_{3^{-}}\right.$ $\left.\mathrm{C}_{1}\right)$; 8 - flyschoid formation $\left(\mathrm{C}_{1} \mathrm{~V}_{2-3}\right)$ and 9-grey-wacke; 10 - gabbro-plagiogranite and migmatite-gneiss-granite formation $\left(C_{1}\right) ; 11$-plagiogranite-dranodiorites and 12dikes of the kunushe complex $\left(C_{3}\right) ; 13$ - 19-kalba complex (13-granite I phase and 14-II phase, 15-aplite-like granite, 16-aplite-pegmatite, 17-oligoclase-microcline, 18 -microcline blocks and 19-rare metal pegmatite); 20 - gabbro-diabase-granite-porhyry formation $\left(\mathrm{P}_{2}-\mathrm{T}_{1}\right) ; 21$ - granitization rocks, migmatite; 22-fractures; 23-orecontrolling deep fault; 24 -focus of ore bringer fusion; 25direction of ore-bearing fluid travel; 26-emanation aureal of rare elements; 27-boundary of Irtysh crush zone; 28pegmatits deposites (Using J. A. Sadovsky's materials).

geochemical specialization on Ta, Li, W, Sn, TR etc. However owing to crystalle-chemical dispersion of rare elements leucogranitic formation has appeared to be loose ore bearing. It is connected with chamber crustbearing pegmatite and fine greisene-quartzvein wolframic demonstration (deposit Dungaly).

Concerning rating of territory prospects it is possible to note, that Kalba-Narym belt is the main rare metal structure of Great Altai. Perspective are the northwest and southeast flanks granitoide of a belt where the detection of new rare metal deposits are latent on depth and hide under a cover of friable deposits. Further we'll briefly consider the characteristics of others granitoidic belts [6]. On the border of Great Altai with caledonion of Gorny Altai Tigireksko-Chernevinsky belt of normal and increased alkali granitoide was generated. The main here are skarnic and greizic deposits with W-Mo (Ekipetsky, Ivanovsky etc.), and in alkaline granite $\mathrm{Nb}-\mathrm{Zr}$ - rare earths mineralization is shown (Azutau). In Gorny Altai 


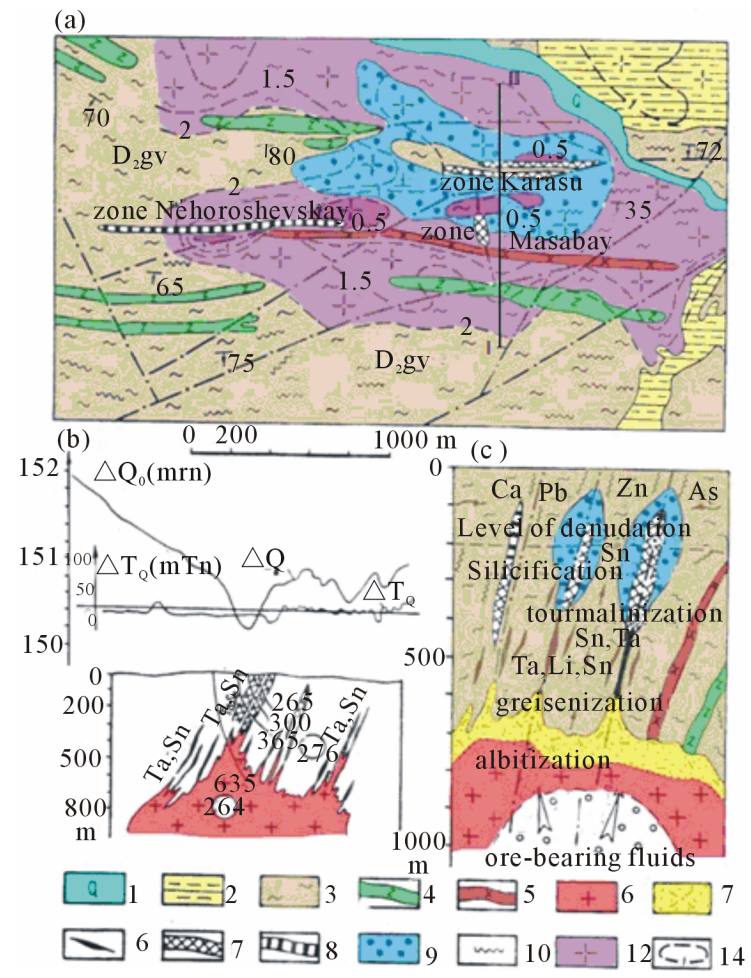

Figure 5. Geological structure of Karasu deposit. (a)-geology plan; (b) - geology-geophysical section; (c)-geologygenetic model [2]. 1-guaternary; 2-gravelly-pebbly sediments of turangy series; 3 - calcic sandstones, aleurolites of kystav-kurchumskoy series $\left(\mathrm{D}_{2} \mathrm{gv}\right)$; 4 -diabase-porphyrites; 5-plagiogranite-porphyry of the kunushsky complex; 6II phase kalba complex granites; 7-albitization and greisening zones with Sn-Ta miniralization; 8-mineralized dikes and apophysis of granites; 9-linear-stockwork zones with cassiterite and 10-sulfite mineralization; $11-$ development areal of stanniferous muscovite-gilbertite-guartz veins; 12 - guartzledges barren; 13-concealed granites and 14-depth of their occurrence $(\mathrm{km})$ according to gravity exporation.

and Chinese Altai in zones of hercinic tectone-magmatic activization Uryl-Koktokay belt of normal and subalkaline granite with pegmatite $\mathrm{Ta}-\mathrm{Nb}-\mathrm{Be}-\mathrm{Li}$ is allocated with greisene and hydrothermal W-Mo-Be deposits (Koktokay, Kalguty, Kokkol etc.) and displays rare earths.

In Kazakhstan continental edges in zones of insideplithic activization (on caledonids border of ChingizTarbagatay and hercineds of Zharma-Saur) AkbiikAkzhailay belt of granit-leukogranite and alkaline granite was located, specialized on rare-metal (W, Mo) and rareearths ( $\mathrm{Zr}, \mathrm{Nb}, \mathrm{TR}, \mathrm{Mo})$ mineralization (deposits Shar, Zhaman-Koitas etc.). With alkaline granites $\left(\mathrm{P}_{2}-\mathrm{T}_{1}\right)$ the formation of rare-earthses pegmatites and riebechitealbite metasomatite with pyrochlor-zircon mineralization are connected (deposit Upper Espe).

In an axial part of Great Altai (on the Kazakhstani border and Gorny-Altaisk continental edges) in Zaysan suturn zone with suboceanic type of earth crust Semi-
palatinsk-Buran-Byrgyn belt of monzonite sienite and granosienite with $\mathrm{Zr}$-Ti geochemical specialization was generated. Granitoid massives of this belt (Preobrazhenska, Buran etc.) are perspective for search of zircon-ilmenite deposits in mesozoic residual soils (Karaotkel deposit), on the account of washupagain which the ilmenite looses (Satpaev placer) are formed.

The revealed laws of formation and spatial accommodation of deposits of rare metals in Kalba-Narym zone and other geological structures are the important criterion for forecasting and searching the new ores objects on East Kazakhstan territory.

\section{Conclusions}

Kalba-Narym is considered as allogenic cluster (Terrane), attached to the structure of the Great Altai in Hercynian collision period. The main ore-bearing structures are confined to clusters of sialitic profile with increased capacity of Meta granite layer and the earth's crust in whole. Granite Belt has a regional growth (the length of more than $500 \mathrm{~km}$ ). Large scale of granitoids expansion emphasizes high energy and material resources for the processes of ore formation. Structural and metallogenic model of Kalba-Narym belt reflects the connection between the ore-magmatic systems with depth zones of the Earth crust and upper mantle, and therefore granitoid belt was formed as a result of long-term abyssal evolution of earth's sial zone matter.

Granite intrusions are presented to be the most orebearing, which are formed in the mobile geodynamic environment that promotes more intensive processes of ore formation in nonequilibrium PT conditions and, ultimately, formation of commercial deposits (Priirtyshsky, Belogorsky solids). On this basis, ore and magmatic systems of varied productivity degrees have been identified and described. Developed geological and genetic models and ore petrochemical typification of granitoids seem to be major factors for rare metal deposits prediction.

Recommendations to geological explorations: Involvement in the assessment reserve perspective areas, and semi-closed and covered unconsolidated sediments (Shulbinsky area, etc.). Additional appraisal of flanks and deep levels of the known ore fields and deposits (Belaya Gora, Bakenny, Upper Baymurza, Yubileiny, etc.). The search for hidden tin-tantalum mineralization in the hidden granite domes of the (Karasu, Shuruk, etc.). Development by small enterprises of small pegmatite deposits with tantalum reserves (Medvedka, Ahmetkino, Tochka, Komarovsky, etc.). Development of new prognostic and search technologies based on modern geological and geodynamic concepts of ore formation, leading ore petrological, geophysical, and mineralogical and geochemical estimation criteria, using high-precise analytical base.

Conducted metallogenic studies have shown that there 
are perspectives in the region to strengthen the mineral resource base for rare metal production.

\section{Acknowledgements}

We think the administration of the East Kazakhstan Territorial Geological Survey (Vostkaznedra) for permission to become acquainted with new results of geological exploration in the territory of the Greater Altai. This study was supported by the Science Foundation of the Ministry of Education and Science of the republic of Kazakhstan.

\section{REFERENCES}

[1] G. N. Shcherba, B. A. Dyachkov, et al., "Great Altai: (Geology and Metallogeny), Book 1: Geology," Gylym, Almaty, 1998, p. 304.

[2] G. N. Shcherba, Kh. A. Bespaev, B. A. Dyachkov, et al., "Great Altai: (Geology and Metallogeny). Book 2: Metallogeny," Gylym, Almaty, 1998, p. 400.

[3] Kh. Bespaev, N. V. Polynsky, G. D. Granzhenko, et al., "Geology and Metallogeny of Southwest Altai: (Within the Limits of Territory of Kazakhstan and China)," Gylym, Almaty, 1997, p. 288.

[4] B. A. Dyachkov, M. A. Mizernaya, N. P. Maiorova and N. A. Zimanovskaya, "Geology and Metallogeny of the East Kazakhstan Region in the Central Asian Mobil Belt," KazGeo, Existing Resource, New Horizons, Almaty, 2012, pp. 40-45.

[5] B. A. Dyachkov, E. M. Sapargaliev, N. V. Polynsky, et al., "Metallogeny of the Greater Altai-The Law of Formation and the Condition of Localization of Ore Deposits," 34th International Geological Congress, Australia, 2012.

[6] B. A. Dyachkov, D. V. Titov and E. M. Sapargaliev, "Ore Belts of the Greater Altai and their ore Resource Potential," Geology of Ore Deposits, Vol. 51, No. 3, 2009, pp. 197-211.
[7] "Big Altai-The Unique Rare Metal-Polimetallic Province of Central Asia," Almaty, 2012, p. 407.

[8] G. N. Shcherba, B. A. Dyachkov and G. P. Nakhtigal, "Metallogeni of Rudny Altai and Kalba," Science, Alma-Ata, 1984, p. 240.

[9] K. R. Kovalev, Y. A. Kalinin, E. A. Naumov, F. Pirajno and A. S. Borisenko, "A Mineralogical Study of the Suzdal Sediment-Hosted Gold Deposit, Eastern Kazakhstan: Implications for Ore Genesis," Ore Geology Reviews, No. 35, 2009, pp. 186-205.

[10] M. S. Rafailovich, M. A. Mizernaya and B. A. Dyachkov, "Large Gold Deposits Hosted in Black Shales: Formation Conditions and Features of Similarity," Almaty, 2011, p. 272.

[11] F. A. Letnikov, "The Fludic Mode of Endogenic Processes in Continental Lithosphere and Metallogeny Problem," GEOS, 2000, pp. 204-224.

[12] B. A. Dyachkov, N. P. Maiorova, G. N. Shcherba and K. A. Abdrakhmanov, "Granitoids and Ores Formation of Kalba-Narym Belt: Rudny Altai,” Gylym, Almaty, 1994, p. 208.

[13] "Mineral Resources of Tantalum, Niobium, Beryllium, Zirconium, and Fluorine: Geology, Economics and Technology," Ust-Kamenogorsk, 2003, p. 416.

[14] B. S. Uzhkenov, G. R. Bekzhanov and L. B. Ivanov, "Rare Metals and Rar Earths of Kazakhstan," Almaty, 2011, p. 277.

[15] V. Ye. Zagorsky, V. M. Makagon, B. M. Shmakin, et al., "Rare-Metal Pegmatites," Novosibirsk: Since, T.2, 1997, p. 285.

[16] R. C. Wang, "Hafnon from the Koktokay \# 1 Pegmatite Dyke, Altai, Xinjiang, China," 34th International Geological Congress, Australia, 2012.

[17] T. Zou, H. Cao and B. Wu, "Pegmatites of Altai Province, Xinjiang," Acta Geologica Sinica, Vol. 2, No. 1, 1989, p. 45. 